\title{
El viaje presuntuoso: Consumir y compartir en Facebook
}

\author{
Zeynep ARDA \\ Izmir University of Economics
}

\begin{abstract}
Resumen:
El individuo de hoy en día acaba siendo en exceso consciente de su apariencia o forma, ya que están constantemente reflejadas en los espejos digitales de las redes sociales. Tenemos tendencia a construir nuestras imágenes según la forma en que queremos que otros nos vean y poco a poco el límite entre nuestra imagen y nuestra identidad se pierde. En esta perspectiva, viajar también se convierte en un campo de consumo presuntuoso - y las redes sociales, en su escaparate.
\end{abstract}

Palabras clave: Consumo presuntuoso; redes sociales; imagen/identidad; estatus social

\section{Conspicuous Travel: Consuming and Sharing on Facebook}

\begin{abstract}
:
The self-conscious individual of our contemporaneity is excessively conscious of her/his appearance or manner, as it is constantly reflected in the digital mirrors of the online social network. We tend to build our images in the way that we want others to see us, hence slowly we losing the boundary between our images and our identities. Within this perspective, traveling also becomes an item of conspicuous consumption - and the online social network, its display.
\end{abstract}

Key Words: Conspicuous consumption; online social networks; image/identity; social status.

\section{Referencia normalizada:}

Arda, Z. (2014): El viaje presuntuoso: Consumir y compartir en Facebook. Historia y Comunicación Social. Vol. 19. Núm. Especial Febrero. Págs. 861-874.

Sumario: 1. Introducción 2. Ir de compras, presumir y el estatus social 3. Compartir las fotos de los viajes, hacer check-ins y turismo en Facebook 4. Aproximación a la identidad de un consumidor 5. Conclusiones 6. Referencias Bibliográficas 7. Notas

\section{Introduction}

Over the past decade, the digital became a seamless part of our daily lives. It is within this context that, we are introduced to the participatory architecture of Web 2.0 and to the concept of online social networking, and we move from the earlier invisibility of communicating in cyberspace to the super-visibility of today. The self-conscious individual of our contemporaneity is excessively conscious of her/ his appearance or manner, as it is constantly reflected in the digital mirrors of the online social network. We tend to build our images in the way that we want others to 
see us, hence slowly we losing the boundary between our images and our identities. Everything we consume, food, music, a nice movie, a walk on the beach or a trip to Hong Kong can be the motive to hit the "Share" button (Figure 1.1). In such a setting, are we consuming for ourselves or for others?

Conspicuous consumption, manifesting itself through "sumptuous weddings and indulgent craze for luxuries" was the norm, rather than the exception in the rigidly class-structured Renaissance city-states, especially Florence (Connell, 2002: 89-90). Competitive displays of wealth to signal family rank - for instance, the competition among the middle-class merchants of the city regarding who was to build the highest tower house as a symbol and visible sign of their wealth and power - were part of this enduring social dynamic (Veblen, 1899; Simmel, 1971; Bourdieu, 1979; Bauman, 2000).

Ritzer, in Theories of Consumption, tells us how the social theory had long favored the production aspect of capitalism while very few social scientists have based their theories on consumption, emphasizing that "no serious theory of contemporary society can ignore the importance of consumption" (2001: 410). Similarly, Baudrillard insisted that it was consumption, rather than production, which was the main drive in the capitalist society (1970/1998). In today's hyper-consumerism, one can observe the outburst of conspicuous consumption that reaches "its audience" through online social networking tools.

Nevertheless, one should not rule out consumption as passive, keeping in mind Michel De Certeau's basic hypothesis that "consumption or use is in fact active and productive" (Sheringham, 2006: 213). According to De Certeau, if consumers are subject to manipulation, as they "deal with" images and representations, they also manipulate the material they receive.

Building his critique on the Marxian concept of "use-value", Baudrillard claimed that all purchases had a fetishistic side - as they always signified something socially. As was elaborated by Roland Barthes, objects always "say something" about their users. And this was, for Baudrillard, why consumption was, and remained more important than production: Because the "ideological genesis of needs" precedes the production of goods to meet those needs (1981: 63). He was especially interested in the cultural mystique added to objects by advertising, which encourages consumers to purchase them as aids to the construction of their personal identity.

In today's society, though the symbols and signs of wealth are different, we observe a consumption race that is similar to the ones in Florence, which has been occurring in a new medium - yet the objective is the same: improving one's social status. On online social networks, or mobile applications like Facebook, Foursquare or Instagram, capitalist competition dictates the communication of what is being consumed via digital images on a daily basis. This race of sharing triggers constant comparison and further competition. Yet social status today is determined by these images - digital images that even lack "the status and power of being a proper image". (Baudri1lard, 2009). 
Figure 1.1 Travel Photos. Source Facebook
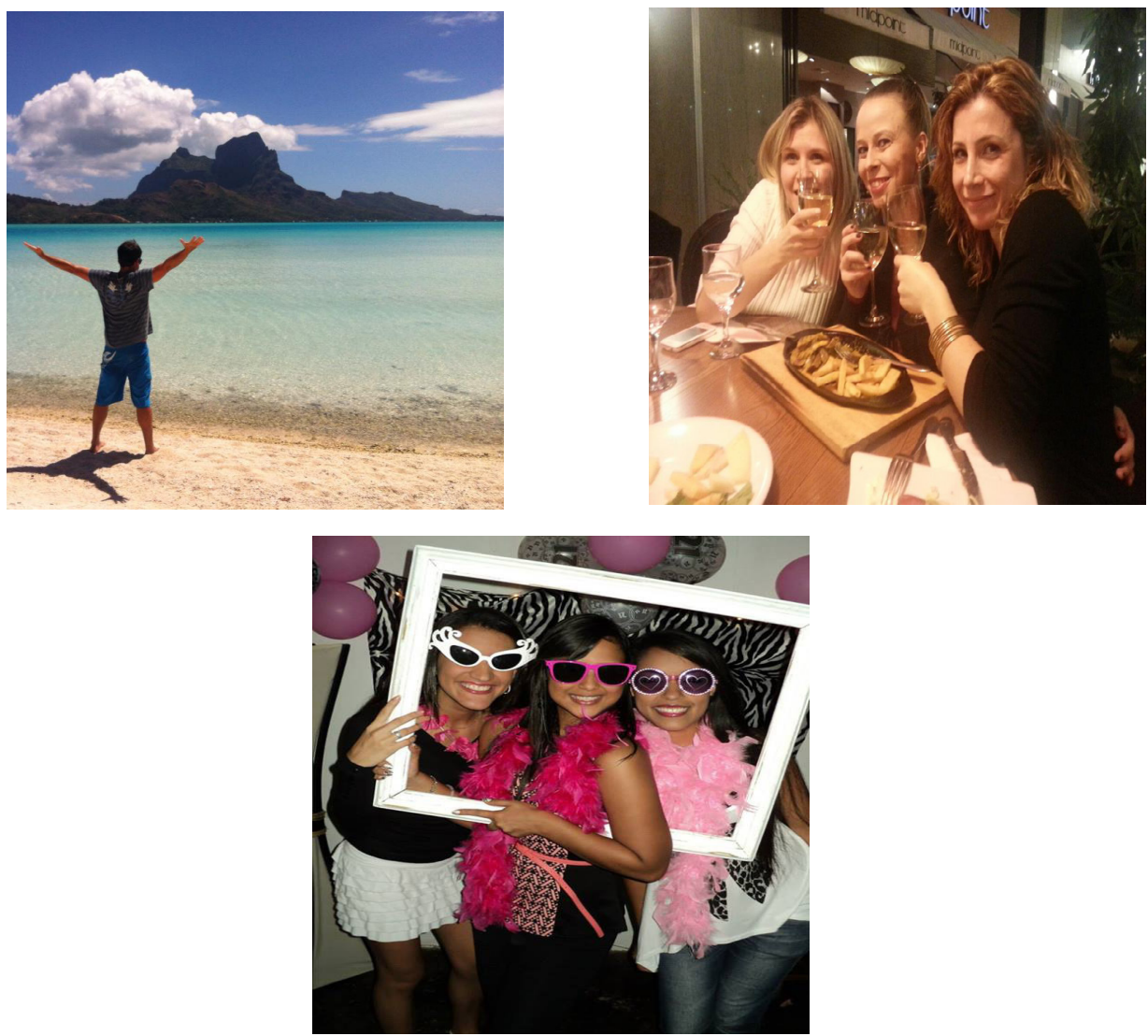

Consumption today "is not just about food, shoes, cars or furniture items" indeed (Bauman, 2000: 74). What we consume, not only in terms of clothing or food but also entertainment, travel or property, become objects of display of an image - construction of an identity based on what we consume, instead of what we produce. One interesting item in this list is travelling, a concept that traditionally referred to an eye opening experience, a trigger of personal development, identity formation and self-esteem, yet which starts to become just another moment to be consumed and shared, as we are always on, always connected and we hardly get to really explore or experience the places that we go to (Turkle, 2011: 156).

In this context, the historical landmarks and tourist attractions become hot spots to "check-in" on Facebook or Foursquare, and the Instagram photos a glimpse of the historical scene, as experiencing the historical monuments and the world heritage sites becomes a "non-experience" of posing for a photograph, checking-in and moving on. 


\section{On shopping, showingand social status}

Considering present-day consumerism, it has been said that the spiritus movens of consumer activity is no longer the measurable set of articulated needs, but "desire" a much more volatile and ephemeral, evasive and capricious, and essentially non-referential entity than "needs", a self-begotten, self-propelled motive that requires no other justification or "cause" (Bauman, 2000: 74).

In other words, in a world already controlled by the Baudrillardian code, consumption ceases to have anything to do with the satisfaction of what we conventionally think of as "needs". We do not buy what we need, but rather what the code tells us we should buy (Ritzer, 1997: 81). Yet, needs themselves are determined by the code so that we end up "needing" what the code tells us we need (Baudrillard, 1981: 82).

But what is this desire, the driving force of our current consumption pattern? The urge to construct one's personal identity always-already sets the individual on a conflicting path. In the friction of two controversial tendencies of adapting oneself to the society and trying to achieve the authentic self, we see what Simmel defined as a state of being both inside and outside of the collective: "On the one hand the individual belongs to a whole and is a part of it, while on the other hand $\mathrm{s} / \mathrm{he}$ is independent and stands opposed to it" (Simmel, 1971: 218-223).

On a more psychological perspective, the controversy of wanting to highlight features that distinguish one's self from the other, co-existing at the same time with the wish to establish similarity and team-up with others (Baumeister, 1986: 18), is at the basis of this ruling desire. In this sense, what we consume starts to be a reflection of our urge to maintain the consistency of our personal narratives and to be different from others. Just as our decisions of consumption become part of the system, the identity of the individual succumbed into the online social network tends to be constructed to fit Baudrillard's "system of objects" as well (1981). It is consumption becoming the language that we speak to one another: "I consume this, what do you consume?"

The presence of Facebook and other similar online social networks in our daily lives today, together with the tendency of constantly sharing glimpses and snapshots of our lives, create a vicious cycle that elaborates the range of our shopping and the trend to let others know of our consumption. In such a context, the act of choosing this object over the other depends on the Baudrillardian cultural mystique, on the social signification attached to the objects through advertising. Yet, in today's society, social media assumes part of advertising's role: We also tend to want what our Facebook friends have.

A highly visual online world, Facebook triggers Bourdieu's theories of social stratification based on aesthetic taste (1979) as indicators of one's social status and how one distances oneself from lower - or simply other - groups. Bourdieu hypothesized that a certain taste is distinctive because it indicated a certain behavior passed on from the parents and internalized at an early age to guide younger generations 
towards their appropriate social positions - a certain cultural capital that marks the difference, hence the distinction. Thus Facebook, as a display of one's social capital, together with one's aesthetic dispositions, becomes highly significant in indicating one's social status in today's society.

According to Bourdieu, tastes in food, culture and presentation are indicators of class because trends in their consumption seemingly correlate with an individual's fit in society (1984: 184). As image starts to take identity over, the urge behind the act of photographing our food, our morning coffee, our new shoes or our last trip to Hawai and sharing it online starts to form the basis of how one chooses to present one's social space to the world. And so does the option of not sharing this information.

What we come to need in capitalism is not a particular object, say a BMW, but rather we seek difference, and by being different we acquire social status and social meaning. What we seek in consumption in modern capitalist society is not pleasure, not the pleasure of obtaining and using an object, but rather difference. This also leads to the view that when they are defined in this way, needs could never be fully satisfied; we have a continuing, lifelong need to differentiate ourselves from those who occupy other positions in the society (Ritzer, 1997: 82).

In this image system, the symbolic value of carrying around a Louis Vuitton bag begins to rate so high that various methods of obtaining the status symbols are introduced. If you cannot afford to buy the bag, you can go ahead and rent it on fashionhire.co.uk - or on any other website of the same genre - that tempts you with its motto: "Why buy, when you can hire?" (Figure 2.1). It's no longer even important to own the status symbols, also considering how fast they are consumed and how soon they fade away.

Figure 2.1 - Why buy when you can hire? Source: www.fashionhire.co.uk.

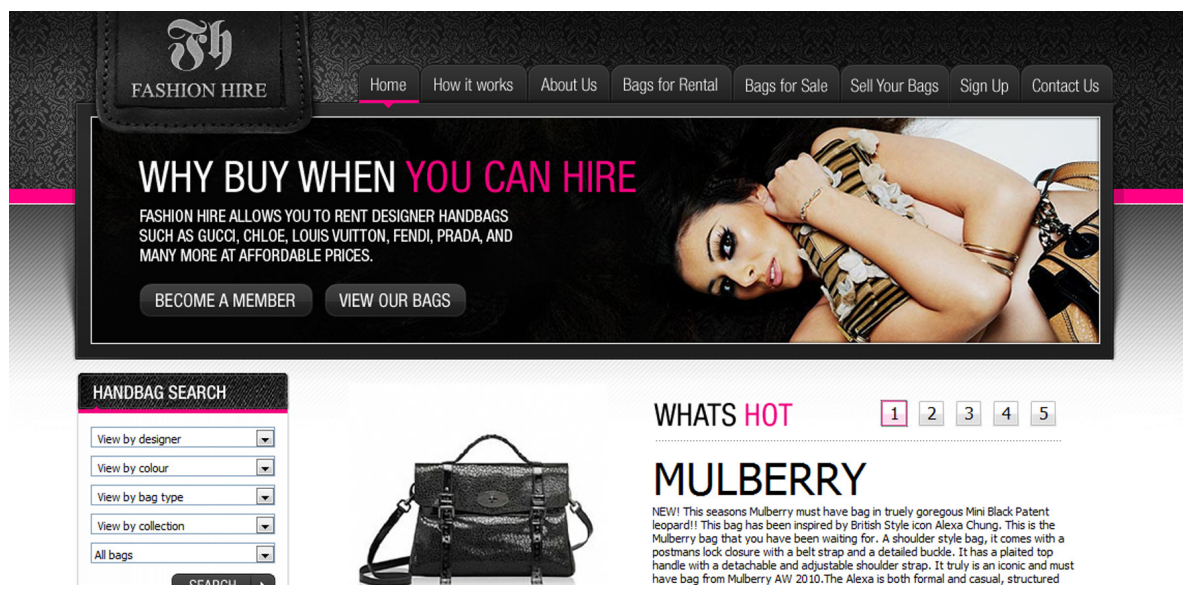


Such a solution is coherent with Michel De Certeau's claim that consumers are "active manipulators" and that "instead of meekly using consumer goods and services as intended, consumers use them in unique ways that suit their own needs and interests" (Ritzer, Goodman \& Wiedenhoft, 2001: 414-415). The irony, then, rests in where the satisfaction from such consumption lies. The idea no longer is to have in order to be, if not to consume only to show that you have - even if momentarily. This is not even an act of economic means, as much as an act of displaying your "distinctive taste" in Bourdieu's terms.

In a world where reality was already overtaken by the image and the illusion, with the latest advances in online and mobile communication, social status becomes more important due to excessive self-consciousness fueled by the online protagonism. Thus, identity construction is impression management. In this context, the never-ending search for new and improved examples and recipes for life is also a variety of shopping and a very significant variety, considering the belief that our happiness depends on personal competence, and that there are so many areas in which we need to be more competent. The abundance of snapshots from other lives that we see on Facebook on a daily basis triggers this dis-ease of upward social comparison (Arda, 2011: 339).

\section{Sharing travel photos, checking-in and facebook tourism}

When we consider the place travel holds within our digital lives, two standpoints can be considered. According to Sherry Turkle, our "tethered" state as we travel withholds us from experiencing the places that we visit - as we are always on, always connected, as we are not leaving our homes behind, but rather bringing them with us (2011: 156-157). Yet, secondly, we may observe another way of Baudrillardian "non-experience" in the way travel becomes just another display of our conspicuous consumption.

The way that we experience a new place is sometimes downsized to arriving, checking-in through Facebook or Foursquare, taking some touristic photographs to document that we have indeed visited the location and then moving on. What is referred as Facebook Tourism in this article is basically this evacuated sense of experience: Travelling as a way of collecting badges, photos and envy from our friends - instead of collecting memories. 
Figure 3.1 - Social Landmarks Around the World. Source: Facebook.
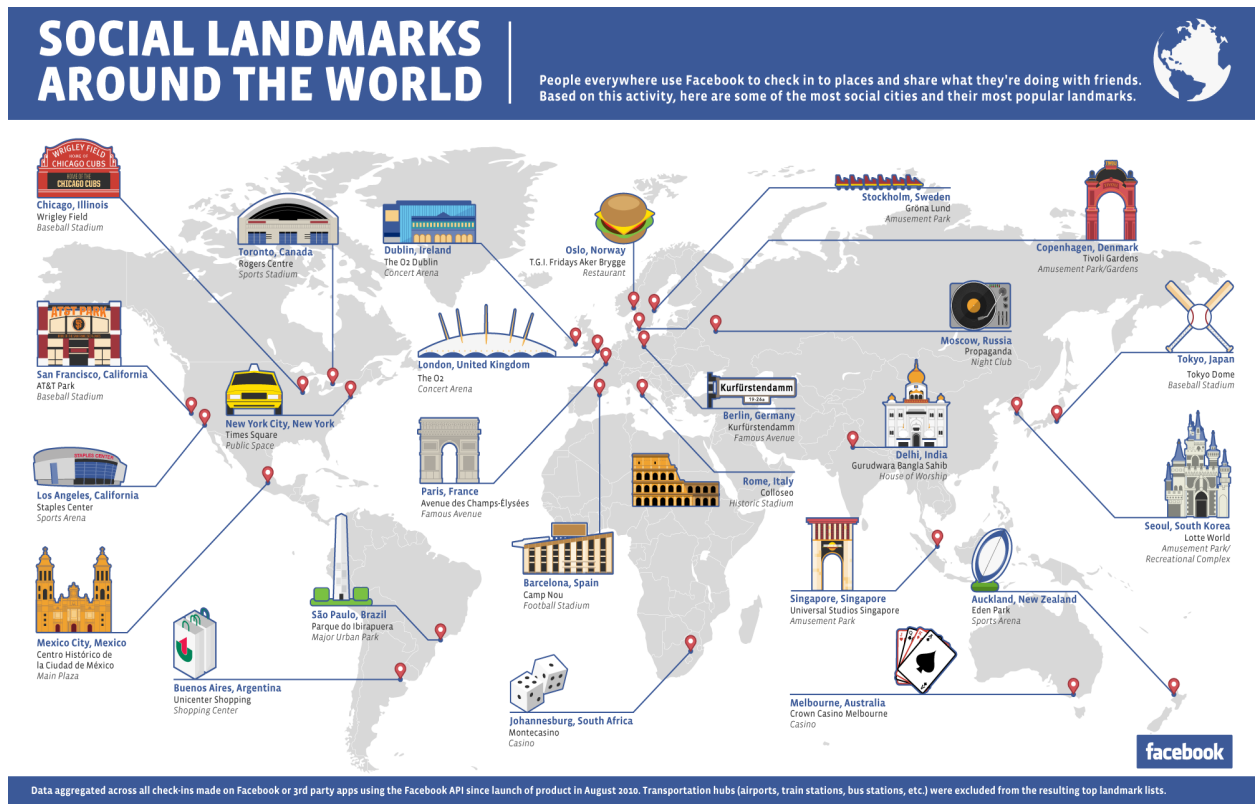

Figure 3.2 - Checking-in on Facebook (screenshot).

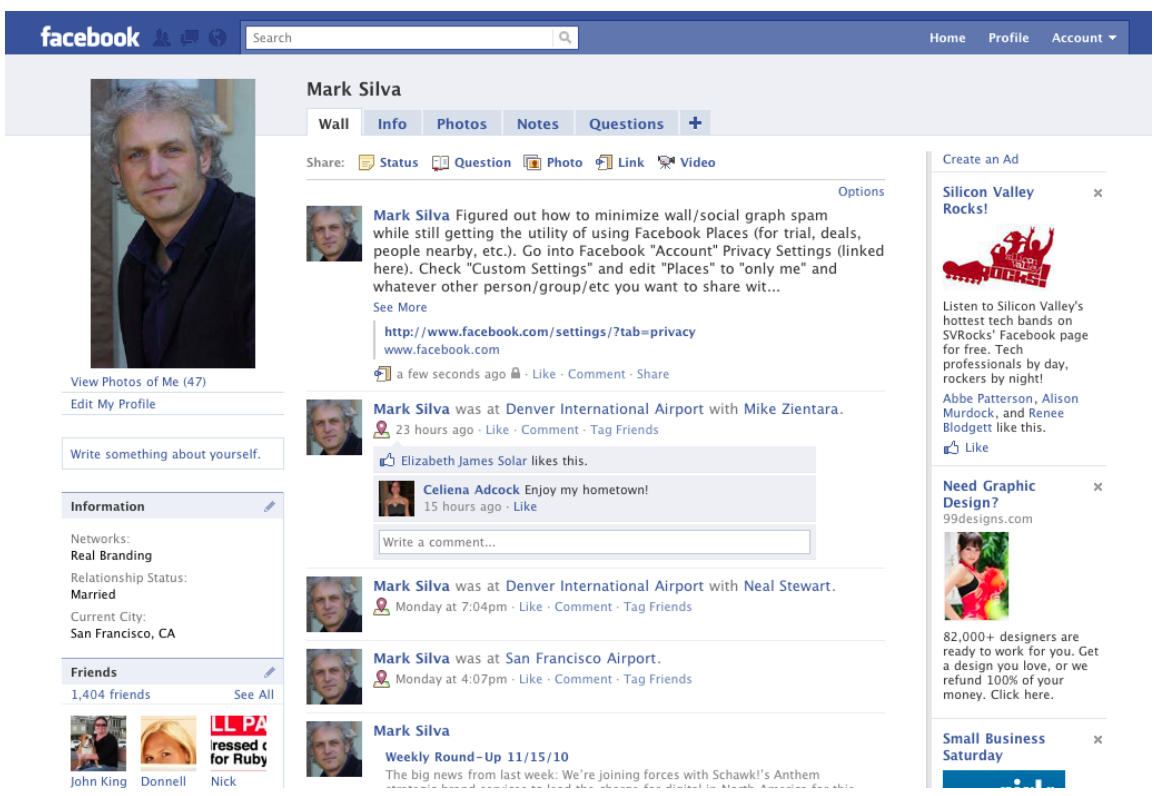


Nevertheless, according to Leanne White, on online social networks and particularly on Facebook, the way "tourism is experienced in a highly visual manner" reinforces the travel experience for the tourist instead of downsizing it. In her research, White explores how the photographs taken, displayed and recorded on Facebook reinforce the experience of travel and furthermore, how these images might influence the travel decisions of those who view the photos (2010).

The most frequently used online social network for documenting travel is Facebook. While the "check-in" feature of the network allows its users to indicate and share their location, the photo albums are the most populated albums of the entire planet. When the photo application was first created, it only allowed users to upload their photos, include them in online albums and enabled others to comment on them. Originally Facebook photos were tagged in just one way - with the names of the people in them. Later the network allowed the users to include the location of the photograph and finally Twitter-like \#hashtags became the norm.

The Facebook team had also stumbled onto a perfect new use for photographs in the age of digital photography. More and more people were starting to carry smartphones with built-in cameras, using the cameras for quick snaps of daily activities. If you always had a camera with you, you could take a picture simply to record something that happened and then put it on Facebook to tell friends about it right away. The tags on a photo automatically linked it to people throughout the site.

Another popular application that has introduced the idea of "checking-in" at the places that we visit is the pioneer of the concept, Foursquare. Only available on mobile devices as a feature, Foursquare tracks its user through GPS and provides a list of the places, restaurants, bars, museums and other points of interest around for the user to "check-in" at any given time. This check-in can be private information that can be considered as noting down the places that you have visited. Alternatively, it can be shared on to Facebook or Twitter to communicate the location of the user to others. These features make Foursquare an important tool in disecting and understanding the concept of Facebook tourism. 
Figure 3.3 - Checking-in on Foursquare (screenshot)
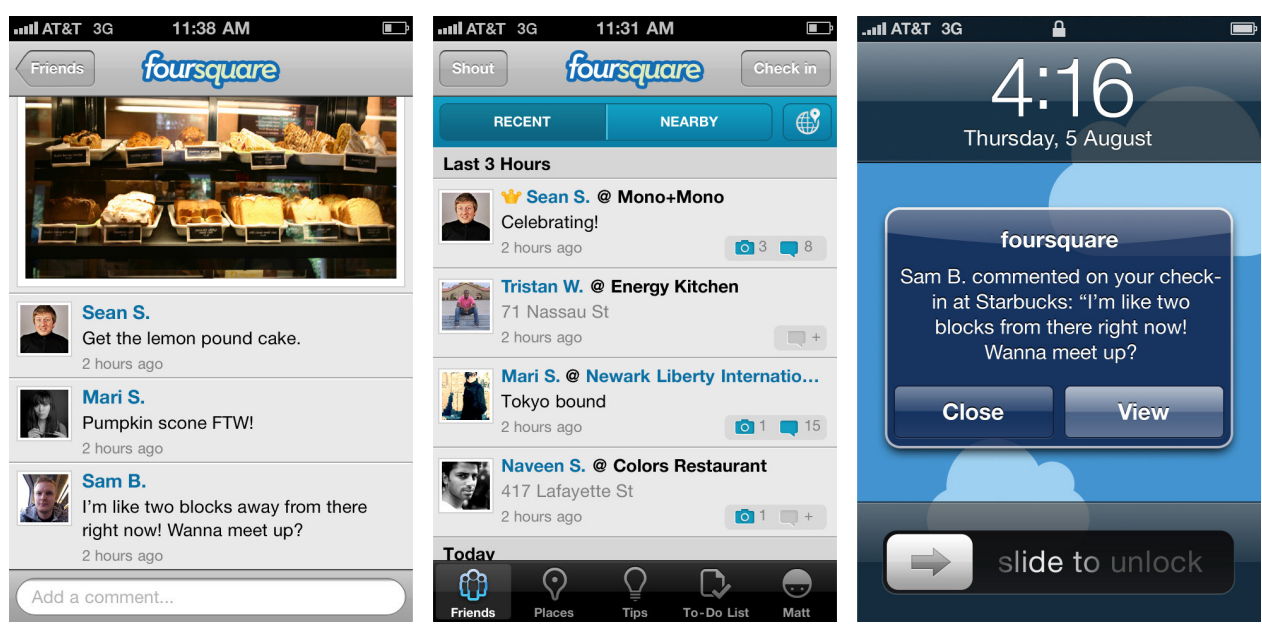

Checking-in on Foursquare or Facebook, using our mobile devices, as we go out or travel, is something simple and fun - until it becomes yet another mirror of conspicuous consumption or until it starts detaching us from our experience of travel. As Sean Parker friskily expresses it in The Social Network (2010), the movie that tells the story of how Facebook first started in 2004, "We lived in farms, then we lived in cities, and now we're gonna live on the Internet!" What was once lived in the street, in the physical space, socializing with our physical identities, communicating with our physical appearances are today visible to a larger public on our Facebook profiles.

As one Facebook user that participated in the Digital Life Scale survey (Arda, 2011) puts it straight out: "Being on Facebook, one accepts being an object of voyeurism and displays a certain level of auto-eroticism (to be specific; selfies (self-portraits) taken at an arms length)". He goes on to define Facebook as a "social toy [that] helps us share and spread our banality". As we start to "live on the internet", we start dedicating less time to "living an actual life". Sherry Turkle, in an anecdote of a trip to Paris with her daughter, explains us how:

Our new experience of place is apparent as we travel. Leaving home has always been a way to see one's own culture anew. But what if, tethered, we bring our homes with us? The director of a program that places American students in Spanish universities once complained to me that her students were not 'experiencing Spain'. They spent their free time on Facebook, chatting with their friends from home. I was sympathetic, thinking of the hours I had spent walking with my teenage daughter on a visit to Paris the summer after she first got her mobile phone. As we sat in a café, waiting for a friend to join us for dinner, Rebecca received a call from a schoolmate who asked her to lunch in Boston, six hours behind us in time. My daughter said simply, "Not possible, but how about Friday?" Her friend didn't even know she was out of town. When I grew up, the idea of the "global village" was an abstraction. My daughter lives something concrete. Emotionally, socially, wherever she goes, she never leaves home. I asked her if she wouldn't rather experience Paris without conti- 
nual reminders of Boston. She told me she was happy; she liked being in touch with her friends. She seemed to barely understand my question. I was wistful, worried that Rebecca was missing an experience I cherished in my youth: an undiluted Paris. My Paris came with the thrill of disconnection from everything I knew. My daughter's Paris did not include this displacement (Turkle, 2011: 156).

Yet another way of missing the experience of a new place is to check-in (so that your friends know that you've been there), to photograph it with a digital camera (everybody wants a souvenir) and to move on without getting more involved (who wants to know what's inside that temple anyway?). As such the physical space also stops being a stage where the interiority of the subject is expressed, reflected and shared, and similarly, travelling stops being an exercise in self-development. Instead, according to Baudrillard, earlier with the television (1987), and lately with the online social network (2009: 49); digitalized human movements are reflected from the screen in the form of film stills, either as a "satellization of the real" or a "hyper-realism of simulation".

The era of hyperreality now begins. What I mean is this: what was projected psychologically and mentally, what used to be lived out on earth as metaphor, as mental or metaphorical scene, is henceforth projected into reality, without any metaphor at all, into an absolute space which is also that of simulation (1987: 128).

According to Seneca, "Travel and change of place impart new vigor to the mind." Yet if travel is stripped off of its possibilities of experiencing something new, if we are to carry our homes to whereever we travel, if travel is reduced to being a non-experience, would it still refresh the mind's perspective?

\section{Towards the identity of a consumer}

The spectacle, as the present social organization of the paralysis of history and memory, of the abandonment of history built on the foundation of historical time, is the false consciousness of time (Debord, 1967: 87).

Several layers of simulation separate us from our true selves in a cyber-hyperreality of the online social network. We communicate who we really are through twofold-manipulated images - firstly, in terms of the non-event - like Facebook tourism, a new, evacuated experience that results from the combination of a faster pace of life and the presence of online social networks in our daily lives: "Shall we still see what's inside the museum, or shall we go on, now that we have already checked-in and taken our photographs" - and secondly, in terms of the possibilities of manipulating the digital image. Hence, in the age of hyperreality, picture-perfect online profiles reflect us better than an involuntary gesture of the hand or a perishing eye-contact in expressing who we are. As we move towards being our images, the social experience of communication converts itself to a "non-experience" (Baudrillard \& Morin, 2004). 
Indeed as the perception of the image is shifted with the digital image that is selected and edited to reflect us on the network, what we understand from photography seems to fade away as well. Blurred, unfocused images on-the-go assume the responsibility of representing how fast we live, how adapted we are to the contemporaneity - there is no time to stop and die in the instance of taking a photograph, the images that adorn our Facebook albums do not have that much time, they are already late.

A photograph is not only an image. It is also a trace, something directly stencilled off the real, like a footprint or a death mask (Sontag as cited in Fletcher, 2001: 488).

A photograph is also a document, an evidence of what is lived. According to the early Surrealists, photography was a technique for revealing the hidden side of reality, "corresponding to unconscious desire rather than narrow reason". Breton linked the revelatory power of photography to the disconnection between act and product - the camera was only an instrument that helped transform perception (Sheringham, 2006: 86).

Travel photographs reduced to selfies taken at one's arm length repeat the effect that Breton describes as the photographic image stripping the things that it records of their "banal obviousness" - via comments on social networking sites (Breton originally considers the captions under the photographs) the "original intensity of the events described" is injected into the photograph (Sheringham, 2006: 87).

When Baudrillard turned his attention to Marshall McLuhan's theory, he progressed beyond Saussure's and Barthes' formal semiology to consider the implications of a historically-understood version of structural semiology, developing ideas about how the nature of social relations is determined by the forms of communication that a society employs. His elaboration of the Simulacra concept involved a negation of the concept of reality, as we commonly understand it. Simulation, Baudrillard claimed, is the current stage of the simulacrum: All is composed of references with no referents, a hyperreality.

Could a photograph vouch for the experience of travel? Or does it turn the experience into a spectacle? Is it important to create evidences of our travels? Is it the photograph, or the act of sharing it online as self-evidence that strips the "original intensity of the event" that is describes?"In certain, almost supernatural states of the soul, the depth of life is revealed in the spectacle, however ordinary it is, we have before our eyes. It becomes its symbol" (Baudelaire as quoted in Sheringham, 2006: 79).

Progressing historically again from the Renaissance, in which the dominant simulacrum was in the form of the counterfeit - mostly people or objects appearing to stand for a real referent (for instance, royalty, nobility, holiness, etc.) that does not exist, in other words, in the spirit of pretense, in dissimulating others that a person or a thing does not really "have it" - to the industrial revolution, in which the dominant simulacrum is the product, the series, which can be propagated on an endless production line; and finally to current times, in which the dominant simulacrum is the model, 
which by its nature already stands for endless reproducibility, and is itself already reproduced (Baudrillard, 1994).

\section{Conclusion}

The "mass communication" sense that we develop through the use of online social networks makes us the online protagonists in creating a world of image and illusion - in such a way that sometimes even we are overwhelmed by our own excessive self-consciousness. Combining such an effect with the capitalistic need for constantly searching for new and improved recipes for life, with the constant reminder that our happiness depends on personal competence we end up in the process of constructing images instead of identities and managing our impression on others instead of simply communicating ourselves.

This competitive drive of the human being does not stem from the survival instinct as much as it does from the capitalist interest. We have to be competitive and competent to get the best jobs, sign up the best clients, hang out with the coolest people, earn a higher salary, buy the biggest house and the ultimate car as well as to find love or to be in a satisfying relationship with the most attractive partner possible - and today we have Facebook to show all that to whom it may concern. This capitalist fantasy, today, works with a formula that had proven successful earlier with the brands. We have to construct a brand identity that your target audience could identify with and build up a relationship on this imaginary identity.

The way identities are displayed on Facebook profiles could be viewed in the light of Daniel Miller's theory of shopping. Miller tells us that the processes of consumption, especially for the female consumers, are connected to the real and ideal social relationships that make up the shopper's world. "Shopping is an active praxis which intervenes and constitutes as well as referring back to relationships" says Miller, and thus, it can "reveal contradictions between self-image and the idealization or denigration of self by others".

The irony here, Miller concludes, is that the primary "purpose behind shopping is not so much to buy the things that people want, but to strive to be in a relationship with subjects that want these things" (1998: 148). Love and devotion play important roles in consumption for Miller, as he suggests that consumer objects can mediate our personal, even romantic, relationships with other people (147). And as such, what we consume, not only in terms of clothing or food but also entertainment, travel or property, become objects of display of an image we strive to be, it skips the stage of being part of "who we are" and goes directly to "who we want others to see us to be". Facebook, not only encourages mass communication of such a process, but also elevates it to a higher level of appearance dominating the identity. 


\section{Bibliography}

ARDA, Z. (2011). Image Becomes Identity 2.0: Contemporary Approaches to the Construction of Human Identity (Doctoral thesis). Castellón: Universidad Jaume I.

BAUDRILlARD, J. (1981). For a Critique of the Political Economy of the Sign. St. Louis: Telos.

(1987). "The Ecstasy of Communication". In FOSTER, Hal (ed.) (2002). The Anti-aesthetic Essays on Postmodern Culture. New York: The New Press. p. 126-134.

(1994). Simulacra and Simulation. Ann Arbor: University of Michigan Press. (2009). Why Hasn't Everything Already Disappeared? London: Seagull Books.

BAUDRILLARD, J.; MORIN, E. (2004). La Violencia del Mundo. Barcelona: Paidos. BAUMAN, Z. (2000). Liquid Modernity. Cambridge: Polity.

BAUMEISTER, R. F. (1986). Identity, Cultural Change and the Struggle for Self. New York: Oxford University Press.

BOURDIEU, P. (1979). Distinction: A Social Critique of the Judgment of Taste. London: Routledge.

CONNELL, W. J. (ed.) (2002). Society and Individual in Renaissance Florence. Berkeley: University of California Press.

DEBORD, G. (1967). Society of the Spectacle. Detroit: Black and Red.

FFRENCH, P. (2005). "Michel Foucault: Life as a work of art". In GRATTON, J.; SHERINGHAM, M. (eds.) (2005). The art of the project: Projects and experiments in modern French culture. Oxford: Berghahn. p. 204-218.

FLETCHER, A. (2001). The Art of Looking Sideways. London: Phaidon.

MILLER, D. (1998). A Theory of Shopping. Ithaca: Cornell University Press.

RITZER, G.; GOODMAN, D.; WIEDENHOFT, W. (2001). "Theories of Consumption”. In RITZER, G.; SMART, B. (eds.) (2001). Handbook of Social Theory. London: Sage. p. 410-427.

SHERINGHAM, M. (2006). Everyday Life: Theories and Practices from Surrealism to the Present. New York: Oxford University Press.

SIMMEL, G. (1971). On Individuality and Social Forms. Chicago: University of Chicago Press.

TURKLE, S. (2011). Alone Together: Why We Expect More from Technology and Less from Each Other. New York: Basic Books.

VEBLEN, T. (1899/2003). The Theory of the Leisure Class. Pennsylvania: Penn State Electronic Classics.

\section{Notes}

WHITE, L. (2010). Facebook, Friends and Photos: A Snapshot into Social Networking for Generating Travel Ideas, in Tourism Informatics: Visual Travel Recommender Systems, Social Communities, and User Interface Design. http://www.igi-global.com/chapter/tourism-informatics-visual-travel-recommender/37762 [23-09-2013]. 


\section{La autora}

Zeynep Arda is currently an Assistant Professor in the Visual Communication Design Department of Izmir University of Economics, Turkey. She received her $\mathrm{Ph} . \mathrm{D}$. degree in Communication Sciences at Universidad Jaume I, Castellón, Spain, with her dissertation "Image Becomes Identity 2.0", on online social networks, how they are shaping who we are and how we communicate with one another. She also holds an M.F.A. degree in Graphic Design from Bilkent University, Ankara, Turkey, an M.A. degree in Interaction Design from Domus Academy, Milan, Italy and a B.S. in Urban and Regional Planning from Middle East Technical University, Ankara, Turkey. Her multi-cultural and multi-disciplinary background forms the basis of her research agenda. 